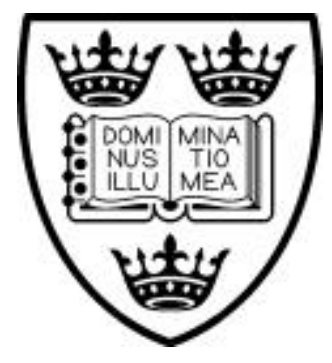

U N I VERSITY OFOXFORD

Discussion Papers in Economic and Social History

Number 34, January 2000

ECONOMIC WELFARE MEASUREMENTS AND HUMAN WELLBEING

AVNer OFFER

REVISED VERSION, MARCH 2000 


\begin{abstract}
GDP per head is not only an economic indicator, but is widely used as a welfare indicator. This use not well founded in economic theory. The paper compares income per head with a three groups of alternative indicators: 'extended national accounts', social indicators, and indicators of subjective well-being. All of these methods indicate a decline in the welfare productivity of GDP goods over time.
\end{abstract}




\title{
Economic Welfare Measurements and Human Well-Being
}

\author{
by
}

Avner Offer

Nuffield College, Oxford

Contact Author: A. Offer <avner.offer@nuf.ox.ac.uk> 


\title{
Economic Welfare Measurements and Human Well-Being
}

\author{
Avner Offer \\ Nuffield College, University of Oxford OX1 1NF
}

Richard Easterlin asked memorably, 'Does economic Growth Improve the Human Lot?'1 This chapter suggests that 'it all depends--on history'. In 1948, a standard System of National Accounts [SNA] was adopted by the United Nations. ${ }^{2}$ Its broad and rapid acceptance facilitated international and inter-temporal comparisons, and generated a competitive preoccupation with economic growth, which continues among economists and economic historians to the present day. Extended into the past, it allowed the measurement of modern economic growth back to its beginnings. ${ }^{3}$ The primary purpose of the SNA was not to monitor human welfare, but to provide an efficient measure of cyclical changes in total economic activity. In that role it is an enduring success. The standard has only changed incrementally at a few points since the 1940s. Its persistence has some of the attributes of technological 'lockin' and path-dependence. The same applies to its more problematic role as a welfare measure: during the 1950s and the 1960s, the output measure of GDP per head, or its annual rate of change, also became a normative benchmark for economic and even social performance, the higher the better.

The 'golden age' of 1950-1970 had barely taken off when the welfare value of economic growth began to be queried. ${ }^{4}$ Books like John K. Galbraith's The Affluent Society, Vance O. Packard's The Waste Makers, David Riesman's Abundance for What and E. J. Mishan's The Costs of Economic Growth, sold well in the late 1950s and early 1960s. They were followed by the anti-materialist 'counter-culture' of the 1960s, and the anti-growth environmentalism of the 1970s. The discipline of economic history was also affected. In

\footnotetext{
${ }^{1}$ Easterlin, "Economic Growth".

${ }^{2}$ Studenski, Income of Nations.

${ }^{3}$ E.g. with great authority by Charles Feinstein for the UK.

${ }^{4}$ Kapp, Social Costs.
} 
Britain, the 'pessimists' in the 'standard of living' debate argued that material improvement was compatible with a decline in well-being. In the United States, the debate on the economics of slavery suggested that efficiency was compatible with human degradation.

The debate on economic growth is usually regarded as an expression of conflicting values. But it might also be the case that the sources of human welfare are historically contingent. As the two decades of the postwar age (c. 1950-1970) came to an end, attention began to shift towards the costs of affluence, ecological, social and psychic. In the poorest of countries, priority was claimed for a set of basic needs over the sacrifices necessary for maximising GDP. Hence, from the late 1960s onwards, the quest for alternatives to GDP as measures of welfare.

'Alternative' measurements of welfare have followed three approaches. The first involved 'extending' the national accounts, to incorporate non-market goods and services, and to eliminate detrimental components. A second approach identified social norms, and evaluated their provision by means of 'social indicators'. A third approach has targeted mental states directly, by means of survey data on reported subjective well-being, and by research on the dynamics of hedonic experience. Cumulatively, these three approaches suggest that the pursuit of welfare is not always satisfied by economic growth alone, and may require different measures at different times.

\section{Extended Accounts}

The micro-economic foundations of the SNA are insecure. The obstacles to the measurement of economic welfare at the micro level are formidable. Much of the difficulty arises from the problem of disaggregation from market prices and quantities to household and to individual consumption. ${ }^{5}$ Aggregating welfare upwards from individuals and households to the level of society is even less tractable. As Amartya Sen puts it, 'personal real income theory translates readily into the theory of real national income [only] if the nation is viewed as a person. ${ }^{6}$ This 'welfarist' position, he says, is 'not outrageously realistic.' Since the nation is not a single

\footnotetext{
${ }^{5}$ Slesnick, "Empirical Approaches".
} 
person, it is impossible to say whether a higher level of GNP actually delivers more 'welfare', even in the narrow utilitarian sense.

In the face of such doubts, the pervasive use of GDP per head as a social welfare measure is a puzzle. The assumption that society is a unitary actor does help to side-step some intractable problems: the difficulty of making interpersonal and intertemporal comparisons of welfare, of taking account of inequality, of compensating losers for Pareto improvements, and of evading Arrow's impossibility theorem. One explanation might be an assumption that underneath we are all pretty much the same, and share a repertoire of innate needs. ${ }^{7}$ When SNA is defended as a measure of welfare, it is on pragmatic grounds, by pointing to positive correlations, often implicit ones, with social indicators such as health, life expectation, and education. ${ }^{8}$ The unitary actor assumption also has a compelling appeal for international comparisons. And sometimes there is an a priori preference from doctrine or self-interest for market-friendly policies that can be justified as maximising GDP, as in the case of 'structural adjustment' in Africa in the 1980s, or market reforms in post-communist Russia. ${ }^{9}$

Unlike the SNA, systems of 'extended accounts' are mostly designed to measure welfare. They start out with the SNA core, and make adjustments on consumption and capital accounts: they typically eliminate some commodities and services which are seen not as final goods in themselves, but as 'regrettable necessities'. Finally, they impute a value to sources of welfare from outside the market. Early estimates were produced in the late 1960s, by Kendrick and Sametz. ${ }^{10}$ Nordhaus and Tobin's 'Measure of Economic Welfare' (MEW) of 1972 was very influential. ${ }^{11}$ This measure eliminated 'regrettables', such as commuting, police, sanitation, road maintenance, defence, and the disamenities of urban life from total

\footnotetext{
${ }^{6}$ Sen, "Welfare " p. 36.

${ }^{7}$ Stigler and Becker, "De Gustibus", p. 76-77; Diener and Suh, "Measuring Quality" p. 445-446

8 Abramovitz, "Retreat"; Dasgupta, Inquiry; Olson and Landsberg, No-Growth Society; Lebergott, Pursuing Happiness; Beckerman, Defence.

9 Dasgupta, Structural Adjustment.

10 Kendrick, "Studies"; Sametz, "Measurement".
} 
output. On the positive side, Nordhaus and Tobin imputed values for household production, and for time available for leisure.

Extended accounting of this and similar kinds has continued into the 1980s and the 1990s, and has included estimates for the United States, Britain, Europe and Australia. ${ }^{12}$ Some of these contained retrospective historical accounts, going back to 1950 for Britain, 1869 for the United States, and all the way to 1788 for Australia. ${ }^{13}$ These indices indicate that extended welfare has been positively correlated with GNP over the long run, though the actual growth rates have differed. ${ }^{14}$

The most compelling implication is that more welfare is derived from non-market than from market activities. Typically the imputed value of leisure equals or exceeds the value of GDP, and household production adds another 25 to 45 percent. About two thirds of output arise outside the market. This salience of non-commodities casts doubt on the welfarist assumption that all well-being can be priced. Leisure and housework dominate the index, and are relatively undifferentiated and slow to change. Hence, the summary indicators are not much use for monitoring cyclical fluctuations. They do satisfy feminist demands for the validation of housework, and in the medium term, provide evidence about trends in nonmarket activities. Together with the rise of the service sector (also poorly estimated in the national accounts), the emergence of extended accounts may be regarded as acknowledging the secular shift of welfare away from its prior association with material production.

Extended accounting relies heavily on the allocation of time. There is also a strand of research which takes time-use as the measure of welfare. This lends itself both to micro and to macro applications. ${ }^{15}$ Gershuny and colleagues are attempting to devise an encompassing

\footnotetext{
${ }^{11}$ Nordhaus and Tobin, "Is Growth Obsolete?"

${ }^{12}$ Kendrick, "Studies"; Zolotas, Economic Growth; Eisner, Total Incomes; Nordhaus, "Reflections"; Beckerman, "Comparable Growth"; Crafts, "Thatcher Experiment"; Snooks, Portrait.

${ }^{13}$ Crafts, "Thatcher Experiment"; Eisner, Total Incomes; Sametz, "Measurement"; Snooks, Portrait.

${ }^{14}$ Nordhaus, "Reflections".

${ }^{15}$ Juster and Stafford, Time; Gershuny and Halpin, "Time Use"; Robinson and Godbey, Time for Life; Schor, Overworked American.
} 
system of accounting based on time use, with a wide international coverage, and going back to the early 1960 s. ${ }^{16}$

The concept of sustainable consumption goes back to Hicks, who defined it as the maximum value of consumption which would leave the individual afterwards as well-off as before. ${ }^{17}$ In their study of 1972 , Nordhaus and Tobin attempted to estimate 'sustainable' welfare, which they took as consumption plus net investment. ${ }^{18}$ They acknowledged the need to take account of the depletion of non-renewable natural resources. This had been anticipated by Kapp in 1950, and several estimates were produced during the 1970s. ${ }^{19}$ Weitzman provided theoretical underpinning: national product net of asset depletion also described the discounted sustainable productive potential of the economy. ${ }^{20}$ A more normative and radical approach was pioneered by Zolotas in 1981. He incorporated pollution and natural resource depletion into a set of extended accounts for the United States for the period 1950-1975, and also imputed shadow costs to some social detriments. ${ }^{21}$ His index of the economic aspects of welfare [EAW] rose progressively more slowly than GNP, and he envisaged a time, a generation hence, when an increment of GNP would produce no welfare at all. He argued that this was a systemic feature: 'beyond a certain point, economic growth may cease to promote social welfare. In fact, it would appear that, when an industrial society reaches an advanced state of affluence, the rate of increase in social welfare drops below the rate of economic growth, and tends ultimately to become negative. ${ }^{.22}$

The national accounts are silent about distribution, reflecting perhaps the utilitarian bias of their origins. Concern over inequality has motivated a good deal of the effort to devise

\footnotetext{
${ }^{16}$ Gershuny et al., "The Time Economy".

17 Hicks, Value, p. 172.

${ }^{18}$ Nordhaus and Tobin, Is Growth Obsolete?

${ }^{19}$ Kapp, Social Costs; Kneese, Economics; Drechsler, "Problems"; Meyer, "Greening".

${ }^{20}$ Weitzman, "Welfare Significance".

${ }^{21}$ Advertising, commuting, and 'corrective' spending on health and education. Crime and divorce were also considered as bads, but kept out of the accounts.

${ }^{22}$ Zolotas, Economic Growth, p. 1.
} 
measures of welfare. ${ }^{23}$ Atkinson's influential index provided a measure for evaluating the effect of income inequality on welfare, which could be adjusted to the amount of inequality tolerated (or desired). ${ }^{24}$ This has been applied to extended accounts by Beckerman, Crafts, and Jackson et al. ${ }^{25}$

After a hiatus in the 1980s, extended accounting took a more radically critical turn. Daly and Cobb continued to develop the Zolotas model: they incorporated inequality (based on Gini coefficients) into a new measure, the Index of Sustainable Economic Welfare (ISEW). ${ }^{26}$ This had the effect of depressing the index: inequality has worsened since the 1970s, and was one of the main offsetting effects of economic growth. ${ }^{27}$ The principle of 'sustainability' in the rubric referred primarily to the depletion of non-renewable resources. Daly and Cobb also removed the imputation for leisure time, on the grounds that it dominated the index and was conceptually unsound. It was this item mainly that that had tended to offset the increase in inequality in less radical accounting exercises. ${ }^{28}$ While GNP continued to grow, the American ISEW declined overall by about 25 percent between the 1975 and 1990, and the British one by almost 50 percent during the same period. ${ }^{29}$ Later versions (fig. 1) show smaller declines. The innovation has caught on, and ISEW measures are available for Australia, Austria, Chile, Germany, Italy, the Netherlands, Sweden, the UK and the USA. ${ }^{30}$ In all of these countries except Italy, ISEW shows growth until the 1970s, with stagnation or decline afterwards. ISEW is explicitly normative, where SNA is only so implicitly. The latest American variant, the 'Genuine Progress Indicator' is bolder still, and introduces imputations

23 Another has been the measurement of household consumption; see Slesnick, "Empirical Approaches".

${ }^{24}$ Atkinson, "Measurement".

${ }^{25}$ Beckerman, "Comparable Growth"; Crafts, Economic Decline, p. 58-60; Jackson, Economic Welfare.

${ }^{26}$ Daly and Cobb, Common Good.

${ }^{27}$ Crafts, Economic Decline, pp. 58-60.

${ }^{28}$ Daly and Cobb, Common Good, p. 412-413; Crafts, Economic Decline, compare table 4, p. 20 and table 17, p.59.

${ }^{29}$ Cobb et al., Progress Indicator, Jackson and Marks, "Economic Welfare". 
for divorce and crime, as well as for various regrettables. ${ }^{31}$ For all their defects, these measures can be seen as effective ways of articulating a normative position on economic change.

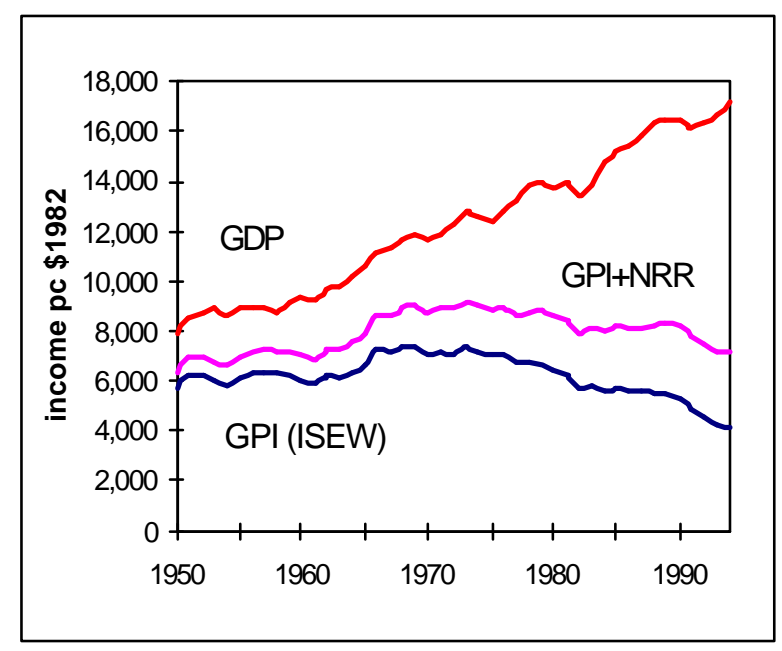

(a) GDP and GPI (ISEW), USA, 1982 prices

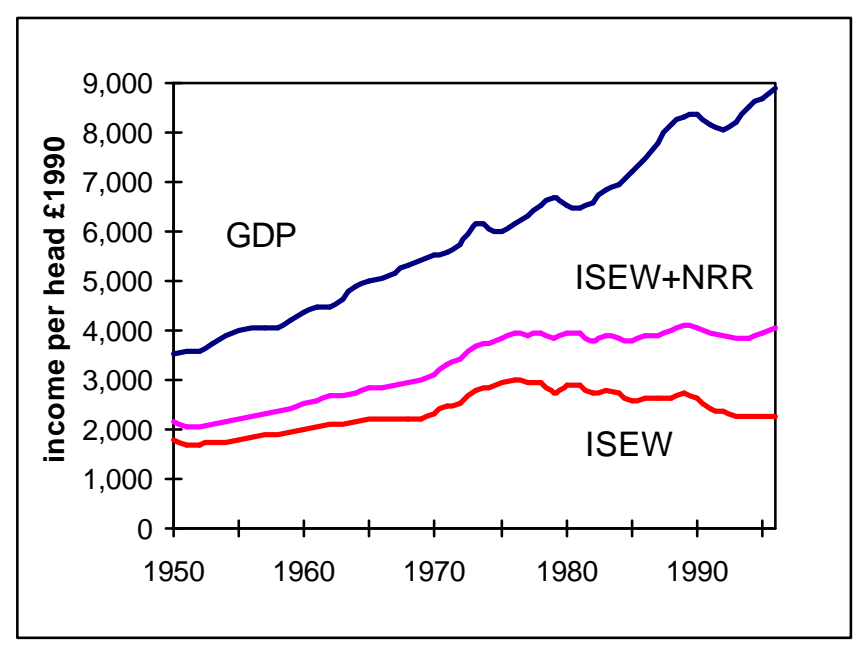

(b) GDP and ISEW, UK, 1990 prices

NNR = Non-renewable resources

FIGURE 1. GNP AND INDEX OF SUSTAINABLE ECONOMIC WELFARE (ISEW), USA AND

UK, 1950-C. 1995.

Sources: (a) Jackson et al. Sustainable Economic Welfare, App. A, p. 40-42 (b) Cobb et al. Genuine

Progress Indicator, table 2, p. 40-41.

If we are to think of society as a unitary actor, then according to the ISEW, the growth in economic activity since the mid 1970s has been producing not an increase, but rather a reduction in aggregate welfare. Since the 1970s, from this perspective, the pursuit of further growth has been irrational. It is only myopia and habit which allow it to continue in the face of negative welfare returns. The problems of aggregation should be borne in mind, and the imputation of environmental depletion is open to criticism. For Britain, however, the inflection point is there even without this imputation.

\footnotetext{
${ }^{30}$ Friends of the Earth, website.
} 
Welfare measures make cognitive demands, which define the user community. The choice of what to measure is essentially normative, i.e. it requires some level of social assent. For wide acceptance, cognitive demands need to be kept to a minimum. It is 'headline' measures that count. Politicians and activists operate in conditions of attention constraint. Hence successful indicators are typically in the form of simple cardinal or interval summary measures, such as the growth rate, inflation, or central bank base rate. Binary indicators, such as the 'poverty line' and the unemployment rate, also have a deceptive simplicity. At the other extreme, academic experts have ample cognitive resources, and compete in analytical subtlety. Their discourse is usually inconclusive. There is a tension then between conceptual rigour, and normative relevance. A successful trade-off is achieved when a measurement norm attains the 'hallmark' of a national or international agency. At that point, conceptual refinement can slow down, and application can begin, although this alone does not guarantee normative success.

Extended accounting is approaching official recognition. Following two decades of research and consultation, in its last revision of the SNA, the United Nations introduced guidelines for an optional set of 'satellite' environmental accounts, designed to integrate with the main core SNA. ${ }^{32}$ 'Sustainability' has become a normative public policy objective in the $\mathrm{UK}^{33}$ This perspective of diminishing returns to economic growth is also captured in a different research programme, the study of normative social indicators.

\section{Social Indicators}

An abiding idea is that access to certain goods constitutes a precondition of welfare. Early examples in Britain were the Poor Law, compulsory primary education, and B. S. Rowntree's 'Poverty Line' of 1901. In the 1960s and early 1970s this approach re-emerged as the 'social indicators' movement. This was also inspired by the idea that real welfare was not captured by

\footnotetext{
${ }^{31}$ Cobb et al., Genuine Progress.

${ }^{32}$ Meyer, "Greening".

${ }^{33}$ Great Britain, Department of Environment, Sustainable Development; and Sustainabiliy Counts.
} 
the SNA indicators. ${ }^{34}$ Typically the goods in question consisted of nutrition, housing, education, health and life expectations, environmental quality, crime, and poverty levels. They might also include such objectives as the freedoms of movement, expression, and political organisation. Implicit in social indicators is some notion of adequacy: there is too little of some things, such as nutrition, housing or education; or too much of others, such as poverty, inequality or crime. Social indicators are rarely scaled in the metric of money, or set within an accounting framework.

By the early 1970s, several leading countries and international bodies had published one-off or serial collections of social indicators. ${ }^{35}$ This enterprise has not abated. Social indicators relied implicitly on a social-democratic consensus, with an egalitarian bias and a quest for social inclusion, as in the Scandinavian 'level of living' surveys. ${ }^{36}$ But there was a lag between impulse and execution, and by the time social indicators were delivered, the impetus of social democracy was spent. Priorities for social expenditure had already been set in the 'golden age' period of expansion and the 1970s were a period of fiscal retrenchment. Social consensus swung away from equality and towards competition, from the left towards the right. The absence of a coherent accounting framework was another disadvantage.

In developing countries, deprivation was not relative but absolute. In the 1970s a 'basic needs' movement identified a bundle of goods that might claim priority over economic growth. ${ }^{37}$ Morris argued that if encompassing was beyond reach, there was a virtue in parsimony. He introduced an unweighted 'Physical Quality of Life Index' [PQLI], made up of infant mortality, literacy and life expectation at age one, as a single measure of welfare. ${ }^{38}$

\footnotetext{
${ }^{34}$ Bauer, Social Indicators.

${ }^{35}$ Terleckyj, Quality of Life.

${ }^{36}$ Nordic Council, Living and Inequality.

${ }^{37}$ Miles, Human Development, p. 153-56.

${ }^{38}$ Morris, Measuring the Condition.
} 
Economic historians adopted the same principle by taking anthropometric measures, primarily heights, as a welfare index. ${ }^{39}$

What followed shows how social indicators not only depend on norms, but can also help to create them. The focus on basic needs came into conflict in the 1980s with the World Bank/IMF 'structural adjustment' policy, and with the increasing market orientation within development economics. The results of these programmes have been mixed, but the impression was that costs fell often disproportionately on the poor. In the late 1980s, dissatisfaction with the 'structural adjustment' programme inspired the creation of a new social indicator, the Human Development Index [HDI]. ${ }^{40}$ This is made up of income per head, life expectation at birth, and an education indicator, expressed in a single figure between 0 and 1. It has gained wide acceptance, and may have played some role in the partial retreat of the World Bank, and its acknowledgment of poverty as a policy objective. ${ }^{41}$ Morris's updated index of 1996, which covered a longer time-span, also exposed the ambiguity of the links between growth and welfare. ${ }^{42}$ Like the SNA, the development indices are another case where a concept has achieved the cognitive punch required for an impact in policy and political discourse. $^{43}$

It is interesting to compare HDI and GNP with Sen's 'capabilities' approach, which has attracted a great deal of discussion. Sen moved from an axiomatic 'welfarist' position to the view that income alone does not satisfactorily capture welfare. In keeping with Liberal values, he has not privileged any particular good. Even under indigence it was necessary to respect individual priorities. ${ }^{44}$ Well-being constitutes having the 'capabilities' to achieve valuable 'functionings'. Both of these categories extend beyond the purely economic. Sen has not embodied his approach in any metrics (it has influenced the Human Development Index),

\footnotetext{
${ }^{39}$ Floud et al., Nutritional Status; Fogel, "Economic Growth".

${ }^{40}$ Desai, "Human Development".

${ }^{41}$ World Bank, Poverty Reduction.

${ }^{42}$ Morris, Measurement.

${ }^{43}$ U.N., Human Development, p. 16-19.
} 
so for all of its normative cogency and conceptual sophistication, his work has not yet achieved the policy impact of the HDI. 'Alternative' approaches, especially Sen's capability/functioning approach, and the various 'sustainability' measures are congruent to some extent with non-utilitarian ethical frameworks, Eastern, Jewish, Greek, Christian, 'Enlightenment', Romantic, which teach that acquisitiveness may be self-defeating, and which highlight other welfare criteria: virtue, stoicism, altruism, approbation, self-realisation.

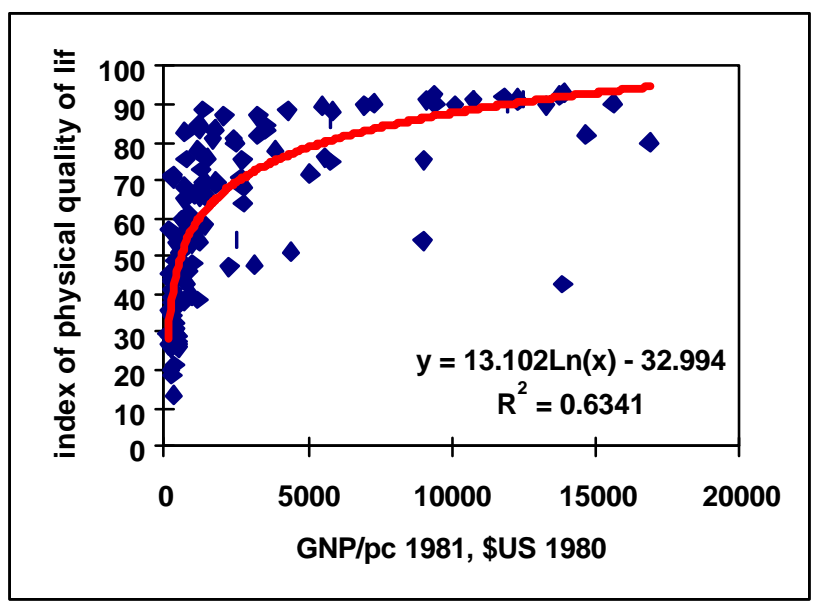

(a) Index of physical quality of life

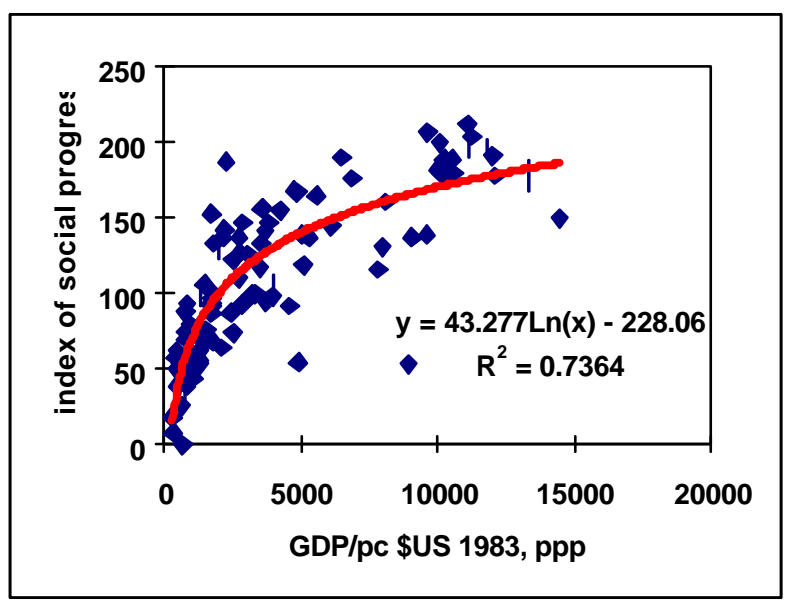

(b) Index of social progress

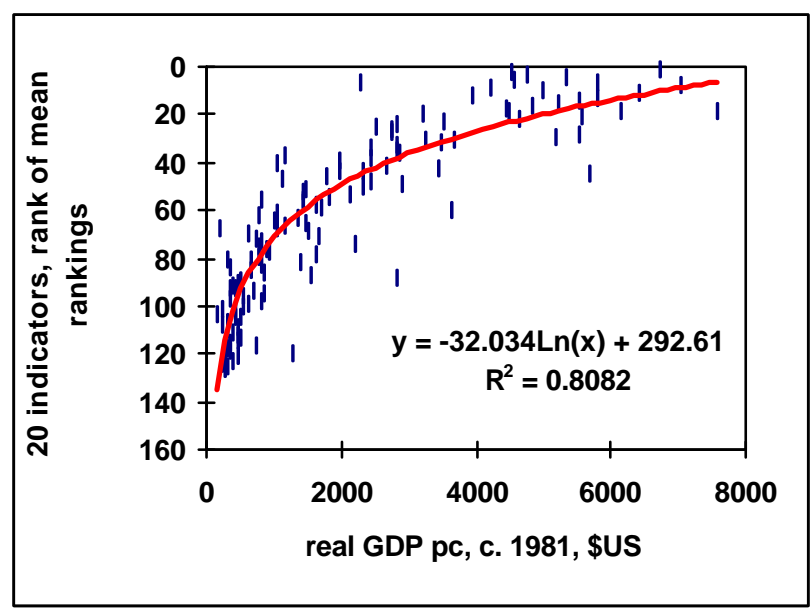

(c) Rankings of multidimensional quality of life index

FIGURE 2. SOCIAL INDICATORS AND INCOME PER HEAD, 1981, 1983. SELECTED COUNTRIES.

Notes: (a) simple average of indices of infant mortality, literacy, and life expectation at age 1.

\footnotetext{
${ }^{44}$ Sen, "Capability".
} 
(b) average of normalized indices of 10 domains, based on 36 indicators. The domains are: education, health, women's status, defence effort, economics, demography, geographic, participation, culture, and welfare effort.

(c) index of 20 indicators for: political rights, civil liberty, household size, militarism, energy consumption, female and children labour participation rates, roads, telephones, life expectancy, infant mortality, medical services, nutrition, literacy, media access, GDP. Rank of mean rankings. Sources: (a) Morris, Measuring the Changing Quality (b) Estes, Trends in World Social Development, table A2, p. 186-188. (c) Slottje et al., Measuring the Quality of Life, table A. 2.2 pp. 96-99.

The most compelling justification for the SNA as a measure of welfare is its correlation with social indicators which enjoy normative consensus as "good things". Hence, it is instructive to test the claims that this correlation exists. What such tests indicate, is that the correlation is strong under conditions of indigence, but loses its power at surprisingly low levels of real income. In figure 2, three such indicators are plotted against income per head. These are Morris's Physical Quality of Life Index (3 indicators), Estes' Index of Social Progress (36 indicators in 10 subgroups), and Slottje's Multidimensional Quality of Life Index. ${ }^{45}$ All three suggest a strong diminution of welfare returns to income at around $\$ 2,500$ 3,000 US in 1981 prices. The HDI already incorporates such a turning point in its premises, by including income per head in its arguments, with a diminishing return to incomes higher than the whole-sample average.

A visual examination of the figures indicates that some countries achieve very high levels of welfare indicators on very low incomes, and that others persist in low welfare indicators on high incomes. These three exercises in social indicators research confirm the extended accounts findings of a curvilinear relation between income and welfare.

A logarithmic curve provides the best fit. These indices are cross-sections at one point in time. Similar patterns also appear to obtain over the long term. The contribution of economic growth to welfare may have been underestimated for the earlier periods of

\footnotetext{
${ }^{45}$ Morris, Measurement; Estes, Social Progress; Slottje, Quality of Life.
} 
economic development, as already noted by Crafts. ${ }^{46}$ The corollary is that its contribution to welfare may be overestimated for the period of affluence. This is suggested by some very crude measures in table 1 . This table takes two measures of welfare, (a) an ad hoc welfare index made up of percentage school enrolment and life expectation, ${ }^{47}$ and (b) the Human Development Index. For both measures, the purchasing power of a 1990 dollar and the income elasticity (in 1990 dollars) are calculated. In the four countries measured, there is a downwards trend in the welfare purchasing power of income over time, although the income elasticity of welfare tends to peak in the interwar years. In brief, then, dollars deliver diminishing returns in simple welfare measures over time, as well as in the cross section.

TABLE 1. MEASURES OF THE RELATION OF WELFARE TO INCOME PER HEAD, C. $1870-1973$

Welfare units per 1990 dollar of GDP per head, 1870-1973

\begin{tabular}{lllll} 
& UK & USA & \multicolumn{2}{l}{ France Germany } \\
1870 & 1.2 & 1.8 & 2.2 & 2.0 \\
1913 & 1.0 & 1.0 & 1.5 & 1.2 \\
1950 & 0.9 & 0.7 & 1.1 & 1.5 \\
1973 & 0.6 & 0.5 & 0.5 & 0.5 \\
\multicolumn{5}{c}{} \\
HDI* per 1990 dollar of GDP per head, 1870-1973 \\
1870 & 1.1 & 1.5 & 1.7 & 1.7 \\
1913 & 1.0 & 0.9 & 1.3 & 1.2 \\
1950 & 0.9 & 0.7 & 1.1 & 1.4 \\
1973 & 0.6 & 0.5 & 0.6 & 0.6
\end{tabular}

Income Elasticity of Welfare Index

UK USA France Germany

$\begin{array}{lllll}1870-1913 & 0.5 & 0.3 & 0.4 & 0.3\end{array}$

$\begin{array}{lllll}1913-1950 & 0.7 & 0.3 & 0.2 & 0.9\end{array}$

$\begin{array}{lllll}1950-1973 & 0.3 & 0.1 & 0.1 & 0.1\end{array}$

Income Elasticity of HDI*

UK USA France Germany

$\begin{array}{lllll}1870-1913 & 0.7 & 0.4 & 0.6 & 0.5\end{array}$

$\begin{array}{lllll}1913-1950 & 0.8 & 0.6 & 0.6 & 2.2\end{array}$

$\begin{array}{lllll}1950-1973 & 0.3 & 0.3 & 0.3 & 0.2\end{array}$

Notes: Welfare index is made up of $\%$ school enrolment+life expectation/2. HDI* is the Human Development Index, with the income element untruncated. Index units multiplied by 100 . The indices are bounded variables but are well short of the maxima even in 1973.

Source: Calculated from Crafts, 'Human Development Index'.

\footnotetext{
${ }^{46}$ Crafts, "Human Development Index".

${ }^{47}$ A more reliable measure than notional literacy, which peaks early.
} 
It could be argued that the simple development indices are misleading, in that the measures used are exhausted under affluence. Measures like HDI and PQLI are oriented strongly towards the priorities of indigence. The most extensive social indicators study so far puts this possibility to the test. ${ }^{48}$ William Easterly used a panel dataset of 81 indicators covering up to four time periods (1960, 1970, 1980 and 1990), in seven domains. ${ }^{49}$ All of these indicators were regressed on income per head, with fixed time effects. The criterion for robustness was that an indicator had an impact on the quality of life that was significant, positive and more important than exogenous shifts. Exogenous shifts capture not the effect of local income, but of global socio-economic progress which may arise from the diffusion of knowledge or of norms. Three methods were used. In the first, all data were pooled, and only time effects were included in the regression. 32 out of 81 indicators passed this test. When country fixed effects were added, the number of robust indicators fell to 10 . With a firstdifferences IV estimator to establish causal effects, only 6 indicators survived out of 69 . Three variables alone passed all three tests: calories per head, protein per head, and telephones per head. The first two, however, are known to have problematic effects on wellbeing once adequacy has been reached. ${ }^{50}$ This, the most extensive social-indicator test so far, has confirmed that the relation of well-being and income per head is weak, both in cross section and over time.

Association between health outcomes and economic status has long been observed internally within countries. ${ }^{51}$ It is not entirely clear how much ill-being arises simply from material deprivation, and how much from the psychic costs of exclusion. There are good descriptive indicators of inequality, such as the Poverty Line, Lorenz Curve, the Gini

\footnotetext{
${ }^{48}$ Easterly, "Life during Growth".

49 (1) rights and democracy (2) political stability and war (3) education (4) health (5) transport and communication (6) inequality and (7) "bads".

50 Offer, "Epidemics of Abundance".

${ }^{51}$ Black et al., Black Report; Marmot, "Social Differences"; Smith, "Healthy Bodies"; Wilkinson "The
} 
Coefficient, Atkinson's index and P-alpha. What is lacking are standard, simple, social indicators of the consequences of inequality for affluent societies, an index of deprivation and detriment similar perhaps to the PQLI or HID. Such indices are currently under construction by Michael Noble and his team at Oxford. ${ }^{52}$ It is also possible, of course, that causation is not exclusively from low status/income to poor health, but also the other way round, from poor health to low status/income.

The HDI has the prestige of UN approval, is widely used and quoted, and has also been used retrospectively, for historical evaluation. ${ }^{53}$ The United Nations has now also laid down a standard for a fifteen-item 'minimum national social data set'.54 But unlike HDI or PQLI, the components do not lend themselves to aggregation, indexation, or a focal-point summary figure. These indicators are all oriented towards development. They are essentially catch-up indices, calibrated to current best practice. They fail to address the original impulse of the social indicators movement, which was finding a way of measuring welfare in affluent societies; not only the welfare of the poor in those societies, but also of those who are working, healthy, and reasonably well-off. How does economic growth affect such people, and is it worth the cost?

\section{Psychological Indicators}

Economic resources are not final goods, but intermediate ones. Pigou conceded that 'welfare consists of states of consciousness only and not material things', and Irving Fisher wrote, 'human beings are ever striving to control the stream of their psychic life by appropriating and utilizing the materials and forces of nature'.55 If we take that argument seriously, then to understand the economy, more needs to be known about the mind. Psychological approaches attempt to reach directly into the experience of welfare. They test the validity of the national

\footnotetext{
Epidemiological Transition".

52 Index 99, "Final Consultation".

${ }^{53}$ Costa and Steckel, "Trends in Health,"; Crafts, Economic Decline and "Development Index".

${ }^{54}$ U.N., "Social Statistics".

${ }^{55}$ Pigou, Economics of Welfare, p.10; Fisher, Interest, p.3.
} 
accounting measure of welfare in two ways: 'static' measures estimate the correlation between SNA goods and psychological indicators of well-being. 'Dynamic' approaches probe deeper into the hedonics of satisfaction. ${ }^{56}$

Like 'human development', the static 'happiness' approach has also produced a measurement standard. This constitutes survey data on responses to a simple question about current subjective well-being on a bounded ordinal scale (1-3, 1-5, 1-7 or 1-10). One variant is the following survey question 'Taking one thing with another, how would you describe your feeling today? Very satisfied, quite satisfied or not so satisfied?' The response to questions of this kind is known as 'Subjective Well-being' [SWB]. The stock of surveys of this kind is very large. ${ }^{57}$ Some time series go back as far as the 1940s. The indicator is crude, but this is not necessarily a defect. It has a defensible empirical validity. ${ }^{58} \mathrm{~A}$ common theme in this literature is that levels of reported well-being are remarkably high in affluent societies. Those describing themselves as unhappy or very unhappy are typically fewer than 15 percent. ${ }^{59}$

Richard Easterlin was originally impressed by an apparent lack of relation between country income and SWB. ${ }^{60}$ This was challenged by Veenhoven, who identified a curvilinear relation, rather like the social indicators in figure $2 .{ }^{61} \mathrm{~A}$ recent comparison of countries was carried out by Diener et al. (fig. 3a). ${ }^{62}$ They found that SWB rose moderately but significantly with income, with a large variance, of which 37 percent was explained. But subsequent analysis of the same data indicated an inflection point at the $75^{\text {th }}$ percentile: above that level, income did not provide any increment to subjective well-being. ${ }^{63}$ But cross-sections do not

\footnotetext{
${ }^{56}$ Kahneman et al., Hedonic Psychology.

${ }^{57}$ Veenhoven, Database.

${ }^{58}$ Veenhoven, "Satisfaction Research"; Diener and Suh, "Differences ".

59 Veenhoven, "Study", table 2, p. 26.

${ }^{60}$ Easterlin, "Does Economic Growth?".

${ }^{61}$ Veenhoven, "Is Happiness Relative?".

${ }^{62}$ Diener et al., "Factors Predicting".

${ }^{63}$ Diener and Suh, "Differences ", fig. 22.1.
} 
establish convergence over time. On the contrary. For the United States, France and Japan, SWB changed hardly at all since 1946, over a period in which real incomes per head have more than doubled (fig. 3 b). ${ }^{64}$

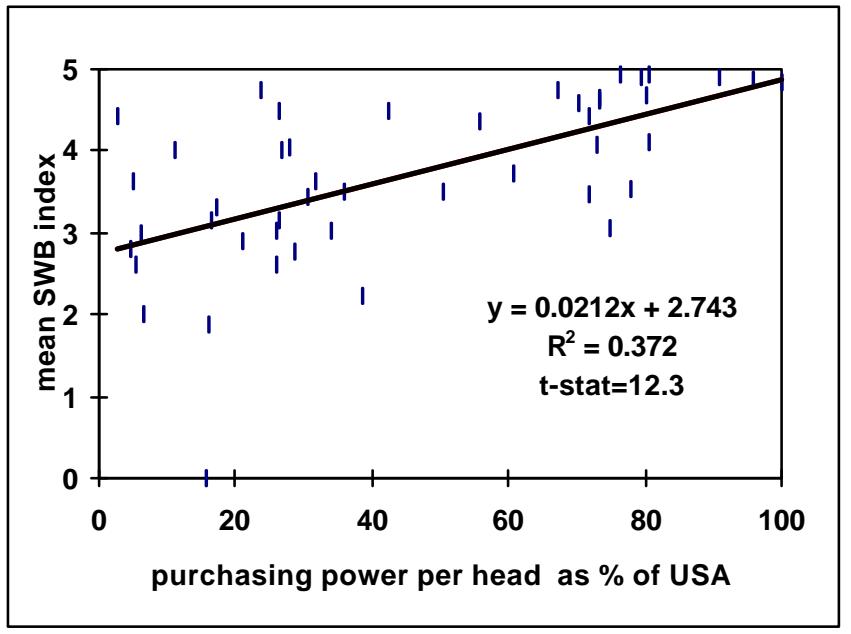

(a) SWB and income, cross-section, early 1990s

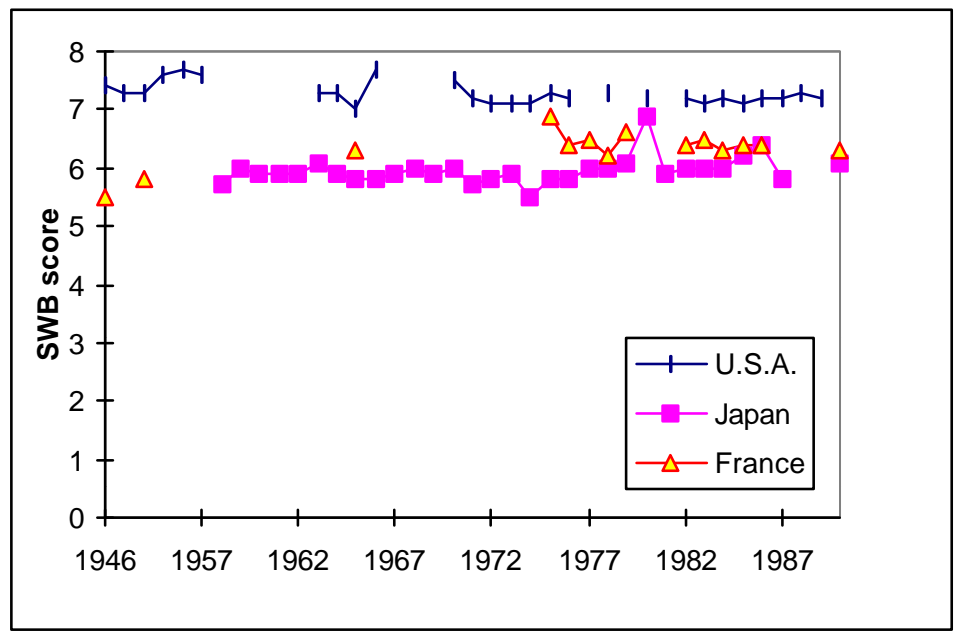

(b) SWB over time, USA, France, Japan

FIGURE 3. SUBJECTIVE WELL-BEING, INCOME AND TIME. SELECTED COUNTRIES.

Note: (b) scale 0 to 10.5 is neutral midpoint.

Sources: (a) Diener et al., "Factors Predicting", table 1, p. 856. (b) Diener and Suh, "Measuring Quality of Life", table 1.p. 211.

This result has been confirmed by surveys of SWB at the individual level. SWB has been correlated with an array of socio-economic determinants and domains. This research was first carried out in cross section on an American national sample in the early 1970s. ${ }^{65}$ The predictive power of each individual determinant was low, and even all of them together accounted for only about half of the variance. Income on its own counted little for happiness, and the relation is again curvilinear: the effect is stronger at lower incomes. The positive effect of income is stronger in cross-section than over time. A large longitudinal study in the United States found a very modest relation of income to well-being $(r=0.12)$, with a

\footnotetext{
${ }^{64}$ Diener et al., "Income and Subjective Well-Being"; "Predicting Subjective Well-Being"; "Quality of Life"; Blanchflower and Oswald, "Well-Being".
} 
curvilinear form, flattening out at about $\$ 6,000-8,000$ (1971-1975). ${ }^{66}$ Interestingly, a rise of income over time for particular individuals produced no improvement at all in well-being. Among the determinants of SWB, the quality of relationships, of leisure, and of work experience counted a considerably more for aggregate well-being than income and consumption measures. ${ }^{67}$ Materialism, a preoccupation with economic well-being, was negatively correlated with SWB, and especially so in those who believe that more money would make one happier. ${ }^{68}$

The determinants of SWB have more recently been investigated on very large samples over time, in both the United States and in Europe. ${ }^{69}$ The findings are consistent with previous ones. They show little variation over time. Absolute income counts for little but relative income (i.e. position in the ladder of earnings) has significant influence on wellbeing, from the second quartile upwards. Misery, i.e. strong negative divergences from the the reference case (white, married, female, employed), is caused primarily by three conditions: non-white race, unemployment, and non-marriage. There are also a number of consistent but weaker effects, such as age (U-shaped). Gender makes no difference. In the European sample there are also very strong country effects. The magnitude of the coefficients is remarkably similar from one large sample to another, which indicates that however crude SWB is as a measure of well-being, it is rather robustly explained. Table 2 is typical.

\footnotetext{
${ }^{65}$ Campbell et al., Quality.

${ }^{66}$ Diener et al., "Income and Subjective Well-Being".

${ }^{67}$ Campbell et al., Quality, p. 80; Levy and Guttman, "Multivariate Structure"; Argyle, "Causes and Correlates", p. 356-359; Headey and Wearing, Understanding Happiness, p. 78-79.

${ }^{68}$ Ahuvia and Friedman, "Macromarketing Model", p. 154, 161.
} 
TABLE 2. HAPPINESS IN THE UNITED STATES (ordered probit),1972-1994

$\mathrm{N}=26,668$, Dependent variable $=$ Reported Happiness on a three-point scale

\begin{tabular}{|c|c|c|}
\hline Variable & Coeff. & Std.error \\
\hline Unemployed & -0.379 & 0.041 \\
\hline Self Employed & 0.074 & 0.023 \\
\hline Male & -0.125 & 0.016 \\
\hline Age & -0.021 & 0.003 \\
\hline Age Squared & 2.77E-04 & $3.00 \mathrm{E}-05$ \\
\hline Education: High School & 0.091 & 0.019 \\
\hline Associate/Junior College & 0.123 & 0.04 \\
\hline Bachelor's & 0.172 & 0.027 \\
\hline Graduate & 0.188 & 0.035 \\
\hline Marital Status: Married & 0.38 & 0.026 \\
\hline Divorced & -0.085 & 0.032 \\
\hline Separated & -0.241 & 0.046 \\
\hline Widowed & -0.191 & 0.037 \\
\hline No. of children: 1 & -0.112 & 0.025 \\
\hline 2 & -0.074 & 0.024 \\
\hline 3 or more & -0.119 & 0.024 \\
\hline Income Quartiles: Second & 0.161 & 0.022 \\
\hline Third & 0.279 & 0.023 \\
\hline Fourth (highest) & 0.398 & 0.025 \\
\hline Retired & 0.036 & 0.031 \\
\hline School & 0.176 & 0.055 \\
\hline At home & 0.005 & 0.023 \\
\hline Other & -0.227 & 0.067 \\
\hline
\end{tabular}

Source: Di Tella et al., "Macroeconomics of Happiness", table 3, p. 20.

The positive cross-sectional correlation of income and SWB within countries has long suggested a link from static to dynamic approaches, and to the 'relative income hypothesis', which states that what counts is not absolute income, but relativities. ${ }^{70}$ From this point of view, if distribution is unchanged, then even a large rise in income will leave no impact on well-being. For example, the large rise in American, French and Japanese incomes since the war has hardly changed their SWB scores (fig. 3b). The reason for this, it is argued, is that as incomes increase, so do consumption norms. ${ }^{71}$ Consumers become habituated to new levels of consumption. Quite independently, Scitovsky reviewed psychological research on arousal

\footnotetext{
${ }^{69}$ Di Tella et al, "Macroeconomics of Happiness"; Blanchflower and Oswald, "Well-Being".

${ }^{70}$ Duesenberry, Consumer Behavior, Hirsch, Limits to Growth.

${ }^{71}$ Easterlin, "Raising the Incomes".
} 
and habituation to probe the dynamics of diminishing returns. ${ }^{72}$ He also drew some normative implications for economic priorities, and questioned whether American acquisitiveness was in fact increasing welfare. The 'Leyden Approach' to welfare research has also found that the individual welfare returns to income follow a curvilinear trajectory, and that the welfare increment declines substantially as income increases. Earning norms drift up with income, though not all the way. A more vivid metaphor, which applies to all three measurement approaches to welfare, is the 'hedonic treadmill': income has to rise in order to sustain satisfaction at a constant level. ${ }^{73}$

The World Values Survey permits a cross-sectional test of the importance of the effect on subjective well-being of relative and absolute income. Figure 3 incidates that in the cross-section absolute income is quite highly correlated with subjective well-being scores. But the same dataset also makes it possible to distinguish whether it is relative or absolute income that produces well-being. Relative income is estimated as the proportion of those who say they are 'very happy' at 'lower', moderate and 'higher' incomes. A regression analysis finds that for the 35 countries included, relative income is significant, and absolute income is not (table 3)

TABLE 3. RELATIVE AND ABSOLUTE INCOME, 35 COUNTRIES,1990s.

OLS with country dummies. Dependent variable is percentage reporting themselves 'Very Happy'

\begin{tabular}{lrr}
\hline Variable & Coeff. & \multicolumn{1}{c}{ t-stat } \\
\hline Constant & 22.88 & 8.50 \\
HIGHER & 2.35 & 2.66 \\
LOWER & -2.70 & -3.06 \\
PPPpc & 0.0005 & 0.97 \\
R-sq. & 0.95 & \\
Adj. R-sq. & 0.93 & \\
Mean dep. var. & 23.4 & \\
\hline
\end{tabular}

Source: Data from Inglehart et al., Human Values, tables 1, V18.

\footnotetext{
${ }^{72}$ Scitovsky, Joyless Economy.

73 Van Praag and Fritjers, "Measurement of Welfare"; Coleman et al., Social Standing, ch. 17; but see Diener et al., "Income and Subjective Well-Being", "Predicting Subjective Well-Being".
} 
The low responsiveness of well-being to income under affluence may arise because people are simply born happy or unhappy, and most are happy already. Longitudinal studies indicate that personality is a strong predictor of SWB.$^{74}$ One review concludes that happiness is more a trait than a state. ${ }^{75}$ A study of separated identical twins suggests that neither social and economic status, educational attainment, family income, marital status or religious commitment could account for more than three percent of the variance in 'happiness'. About half the variance was associated with genetic variation. Subsequent re-testing suggested that about 80 percent of the stable element in well-being was heritable. ${ }^{76}$

Culture provides another element of stability. Affluent industrial societies with similar levels of income per head report very different levels of subjective well-being, with a gradient coming down from the Nordic countries, which have very high levels, the Englishspeaking countries at an intermediate level, The Catholic middle and south of Europe lower still, and Japan lowest of all. ${ }^{77}$ Inglehart regards this gradient as a representing an adaptation or adjustment to affluence. He classifies societies on two value orientation dimensions, the pursuit of economic security and deference to traditional authority. As societies become more affluent, they move gradually away from both. This implies that the experience of affluence reduces concerns about economic security, and that culture adapts, albeit slowly, to changes in economic endowment. ${ }^{78}$

In affluent societies, culture appears to affect SWB more strongly than income. Japan and Australia had comparable incomes per head in the early 1990s but Australia scored an SWB of 1.02 (mean of 60 countries at 0), with Japan at the other end of the affluent country distribution, at -.86. 'Individualism' predicted SWB better than income: once controlled for

\footnotetext{
${ }^{74}$ Headey and Wearing, Understanding Happiness, p. 84-85.

75 Stones et al., "Happiness".

${ }^{76}$ Lykken and Tellegen, "Happiness"; Stones et al., "Happiness", p. 135.

77 Inglehart et al., Human Values, table V18.

78 Inglehart, Modernization, ch. 3.
} 
'individualism', the correlation of income and SWB disappeared. ${ }^{79}$ This suggests that that the hedonic ideal of distinctly individual welfare, utility or happiness might be an ethnocentric cultural construct that is peculiarly Nordic, Anglo-Saxon or Protestant. European surveys of SWB over time have produced very large country coefficients. ${ }^{80}$ The long-term persistence of SWB scores in particular countries even brings to mind the idea of 'national character'. It should be said that the linear correlation of income and SWB among nations is not a timeseries, but a cross-section. It cannot be regarded as indicating a temporal convergence, given the stability of country SWB scores over time.

An early inspiration of the social indicators movement was the 1960s 'rediscovery of poverty', which redefined it as a relative rather than absolute form of deprivation. The most consistent application of the relative income concept has been by Easterlin, who has hypothesized that expectations are formed by comparisons with parents, and that demographic cycles mean that (in the United States, at least, since the Second World War), different cohorts have different expectations. ${ }^{81}$ Satisfaction has moved pro-cyclically, with the young adults of the 'golden age' exceeding their own modest expectations, while the successor 'baby boom' having its higher expectations disappointed. A related perspective is Inglehart's long-standing study of 'post-materialism'. The argument here is that the post-war cohorts have shifted their preferences from economic to non-economic rewards, as a result of their experience of economic security. ${ }^{82}$

A different psychological approach is to investigate the hedonic dynamics of satisfaction, which explain why people might make choices which do not improve their welfare. This approach presents a more nuanced account of satisfaction than the crude measure of SWB. In welfare economics, it is assumed axiomatically that the consumer is well-informed, self-aware, consistent, and acquisitive. These assumptions are necessary if

\footnotetext{
${ }^{79}$ Diener et al., "Factors Predicting ", p. 860-862.

${ }^{80}$ Di Tella et al., "The Macroeconomics of Happiness".

${ }^{81}$ Easterlin, Birth and Fortune.

${ }^{82}$ Inglehart, Modernization.
} 
'revealed preference' is to equal welfare ${ }^{83}$ Other approaches do not have such confidence in the cognitive abilities of the consumer. That individual choice might not maximise welfare is an old but neglected theme in welfare discourse. The Victorians distinguished between the deserving poor, who had suffered from adversity, and the feckless and undeserving, who had brought about their own misfortune. B. S. Rowntree made a distinction between 'primary poverty', which was caused by the absence of subsistence resources, and 'secondary poverty', caused by impulsive consumption and poor resource management. ${ }^{84}$ This is brought out by the difference between a 'social indicator' poverty line, which focuses on normative consumption, and a money metric one, which merely measures access to resources. Economists committed to rational choice might regard 'secondary poverty' as reflecting legitimate lifestyle choices. ${ }^{85}$

There is a large programme of empirical research into the determinants of choice, which queries the empirical validity of the axioms of rationality. This is not very damaging to SNA welfare measures, since, as we have seen, their micro-foundations are already insecure. These lines of research have not so far provided direct measures of the validity of welfare aggregation, but rather implicitly query the premises of consumer sovereignty. This effort has highlighted a sequence of systematic and recurrent deviations from normative optimising choice behaviour. ${ }^{86}$ The most robust ones appear to be asymmetric valuation of gains and losses, and the 'endowment effect' by which goods acquire a value once they have entered into possession. If correct, these findings cast further doubt on the possibility of compensating losers, and on the notion of 'opportunity cost'. Research in the hedonics of satisfaction continues. It stresses that satisfaction depends on habituation, anchoring, contrast and temporal effects; that the experience of satisfaction varies with time, and changes between decision, experience and retrospection. ${ }^{87}$

\footnotetext{
${ }^{83}$ Sen, "Income Comparisons".

${ }^{84}$ Rowntree, Poverty, ch. 5.

${ }^{85}$ Hagenaars et al., "Patterns of Poverty", p.26.

${ }^{86}$ Rabin, "Psychology".

${ }^{87}$ Kahneman, "Objective Happiness", 14-21.
} 
Under affluence SWB appears buoyant and quite stable, and responds quite sluggishly to economic indicators, both stagnation and growth. It is poorly correlated with income in affluent societies, and highly correlated in poor countries, confirming the diminishing returns to income detected in social indicators research. ${ }^{88}$ Both extended accounting and static psychological indicators suggest that well-being is derived to a great extent outside the market, from human relations in the workplace, the family, and from other forms of attachment. The psychic payoff of rising absolute income is small, but gains in relative income are rewarding. There are high levels of satisfaction with stable attributes which cannot easily be changed, such as personality, gender, and nationality. Stability and habituation appears to promote well-being.

This also suggests that novelty may undermine it. New rewards are compelling, while their costs are not yet known. Economic competition is driven by novelty and innovation, which stimulate myopic rather than informed choices. In the absence of prior experience, new forms of stimulation are highly compelling. Innovation devalues existing prudential conventions and norms, and is to that extent destructive of existing psychic and social capital. Diener found that SWB is inversely related to the pace of economic growth ${ }^{89}$ Cheap alcohol, drugs, tobacco, fast food, are all innovations which it has taken society decades to adjust and to cope with.

\section{Conclusion}

'Alternative' measures of welfare provide a great variety of indicators, in cross-section and over time, international, intra-national, and individual. A common pattern emerges: the relation of economic welfare and welfare overall is historically contingent. They all suggest a curvilinear relationship between economic welfare and human welfare. Using extended accounting and social indicators, international comparisons suggest an historical cycle of two periods. In the first, economic growth provides high welfare payoffs, as basic deprivations are remedied and basic needs are satisfied. In the second phase, GDP goods provide diminishing,

\footnotetext{
${ }^{88}$ Veenhoven, "Satisfaction Research", p. 25.
} 
steady or even negative returns, depending on the measure used. This pattern can be fitted either to logistic or to power curves. A logistic curve model was first proposed by Xenophon Zolotas in 1981. He described three phases of in the relation of income and welfare, of privation, steady improvements and declining ones, respectively. ${ }^{90}$ More graphic metaphors might be the economy of deprivation and the economy of satiation; or the economy of pain followed by the economy of pleasure. For social indicators the logarithmic curve relation of welfare to income may be more appropriate. The three studies presented in figure 2 , as well as the HDI, all have in common the initial steep rise, followed by an increasingly flat trajectory.

Subjective individual welfare also follows a similar log-normal or power curve response to economic welfare. ${ }^{91}$ The cross-sectional international comparative relation of subjective well-being with income is positive, linear and fairly weak; it disappears when controlled for relative income. The temporal relation for individual countries is almost completely flat. This is consistent with low psychic welfare returns to rising economic growth, the classic 'hedonic treadmill'.

If it is true that GDP goods and services have delivered and are delivering diminishing welfare returns, the question is why. It is premature to attempt to answer it here, but a few observations might be ventured. Both ecological and psychological approaches have one notion in common, namely that affluence produces congestion. In both cases, the affluent economy produces more than it can absorb. The ecology cannot absorb the extra energy, the extra traffic, the extra pollution, without incurring costs that equal or exceed the benefits. Likewise, the abundance of psychic reward under affluence leads to satiation and habituation. These are simple-minded metaphors that require much greater analysis and empirical study.

But policy cannot wait. Alternative accounting of welfare is pragmatically motivated, and even at this stage, it has some implications for policy. (a) In the most advanced economies, the increased supply of GDP goods and services is not the highest priority. This

\footnotetext{
${ }^{89}$ Diener et al, "Income and Subjective Well-Being"; "Predicting Subjective Well-Being".

${ }^{90}$ Zolotas, Economic Growth, fig. 1, p. 16.
} 
may already be reflected in the shift of policy priorities away from the golden-age preoccupation with growth, to the pursuit of macro-economic stability in the period that followed. It does not follow that this shift was welfare-improving overall, since it was accompanied by a rising inequality and unemployment. (b) For policy to find a coherent focus, it requires a better understanding of hedonic dynamics. High levels of well-being are already pervasive, and it is evidently difficult to improve them much further by raising incomes overall. What is needed is a more systematic targeting of ill-being, its determinants, and the economic costs of its amelioration, to make the reduction of ill-being the focus of international competition: of such things as life expectation, material deprivation, the prevalence of crime and the severity of punishment, ethnic, social and political exclusion and repression, family structure and breakdown, mental health, suicide, morbidity, education, quality of working life, job security, access to health care, urban congestion and sprawl, and perhaps also of the quality of personal and social interaction. ${ }^{92}$ It might be more useful to shift the focus of measurement from happiness to unhappiness. There is a view that ill-being does not belong on the same dimension as well-being. ${ }^{93}$ 'Prospect theory' argues that losses are more acutely experienced than gains. Unemployment and discrimination have a much more powerful effect on well-being than material gains. ${ }^{94}$ It may be easier to reach consensus about welfare bads than about welfare goods.

This does not mean that GNP goods have lost their relevance permanently. A society dependent on exponential growth for a stable experience of well-being might suffer badly if growth is withdrawn. Many societies have yet to arrive at that state of abundance, and can still anticipate large welfare returns to growth. And a shift away from GDP goods towards leisure or short-term gratification might eventually return us to the economy of pain. Longer life expectation, high dependency rates and shorter working lives suggest that material

\footnotetext{
${ }^{91}$ Kahneman, "Objective Happiness", p. 17; van Praag and Frijters,"Measurement", p. 419-420.

92 Doyal and Gough, Human Need.

${ }^{93}$ Bradburn, Psychological Well-Being; Diener and Emmons, "Positive Affect".

${ }^{94}$ Campbell et al, Quality, fig. 2-5, p. 52-53; Blanchflower and Oswald, "Well-Being", p. 20.
} 
scarcity could be a problem in the future as much as in the past. In other words, that the determinants of welfare are historically contingent. How contingent? this is one of the challenges for economics and history in the twenty-first century.

\section{REFERENCES}

Abramovitz, Moses. "The Retreat from Economic Advance: Changing Ideas about Economic Progress". In Progress and its Discontents, edited by Gabriel Almond, Marvin Chodorow, and Roy Harvey Pearce. Berkeley, 253-279: University of California Press, 1982.

Ahuvia, Aaron C. and Friedman, Douglas C. "Income, Consumption, and Subjective WellBeing: Toward a Composite Macromarketing Model." Journal of Macromarketing 18, no. 2 (1998): 153-168.

Ainslie, George. Picoeconomics: The Interaction of Successive Motivational States within the Person. Cambridge: Cambridge University Press, 1992.

Argyle, Michael, "Causes and Correlates of Happiness". In Well-Being: The Foundations of Hedonic Psychology, edited by Daniel Kahneman, Ed Diener and Norbert Schwartz, 353-373. New York: Russell Sage Foundation, 1999.

Atkinson, Anthony B. "On Measurement of Inequality." Journal of Economic Theory 2, no. 3 (1970): 244-263.

Bauer, Raymond A., ed. Social Indicators. Cambridge, Mass.: M.I.T. Press, 1966.

Beckerman, Wilfred. In Defence of Economic Growth. London: Jonathan Cape, 1974. . "Comparable Growth Rates of "Measurable Economic Welfare": Some Experimental Calculations." In Economic Growth and Resources, vol. 2, edited by R.C. O. Matthews, 36-59. London: Macmillan, 1980.

. "Is Economic Growth Still Desirable?" In Explaining Economic Growth: Essays in Honour of Angus Maddison, edited by Adam Szirmai, Bart van Ark, and Dirk Pilat, 77-100. Amsterdam: North-Holland, 1993.

Becker, Gary S. and Mulligan, Casey B. "The Endogenous Determination of Time Preference." Quarterly Journal of Economics 112, no 3 (1997): 729-758.

Black, Sir Douglas, Whitehead, Margaret, Townsend, Peter, et al. Inequalities of Health: The Black Report. Harmondsworth: Penguin Books, 1988.

Blanchflower, David G. and Oswald, Andrew J. "Well-Being Over Time in Britain and the USA." Unpublished Paper, 1999.

Bradburn, Norman M. The Structure of Psychological Well Being. Chicago: Aldine, 1969.

Campbell, Angus, Converse, Philip E. and Rodgers, Willard L.. The Quality of American Life: Perceptions, Evaluations, and Satisfactions. New York: Russell Sage Foundation, 1976.

Clark, Andrew E. and Oswald, Andrew J. "Unhappiness and Unemployment." Economic Journal 104, (1994): 648-659.

Cobb, Clifford, Halstead, Ted and Rowe, Jonathan. The Genuine Progress Indicator: Summary of Data and Methodology. San Francisco, 1995.

Coleman, Richard P., Rainwater, Lee and McClelland, Kent A.. Social Standing in America: New Dimensions of Class. London: Routledge \& Kegan Paul, 1979.

Costa, Dora L. and Steckel, Richard H. "Long-Term Trends in Health, Welfare, and Economic Growth in the United States." In Health and Welfare During Industrialization, edited by Richard H. Steckel, Richard H. and Roderick Floud, 4790. Chicago: University of Chicago Press, 1997.

Crafts, Nicholas, F. R. "Was the Thatcher Experiment Worth It? British Economic Growth in a European Context." In Explaining Economic Growth: Essays in Honour of Angus 
Maddison, edited by Adam Szirmai, Bart van Ark, and Dirk Pilat, 301-326: North-

Holland, 1993.

. Britain's Relative Economic Decline 1870-1995: A Quantitative Perspective.

London: Social Market Foundation, 1997.

. "The Human Development Index and Changes in Standards of Living: Some

Historical Comparisons." European Review of Economic History 1, no. 3 (1997): 299322.

Daly, H. and Cobb, J. For the Common Good: Redirecting the Economy Towards

Community, the Environment, and a Sustainable Future. London: Green Print, 1989.

Dasgupta, Partha. An Inquiry into Well-Being and Destitution. Oxford: Clarendon Press, 1993.

Dasgupta, Bilplab. Structural Adjustment, Global Trade and the New Political Economy of Development. London: Zed Books, 1998.

Desai, Megnhad. "Human Development: Concepts and Measurement." European Economic Review 35, (1991): 350-357.

Diener, Ed, and Emmons, Robert A. "The Independence of Positive and Negative Affect." Journal of Personality and Social Psychology 47, no. 5 (1985): 1105-1117. Sandvik, Ed and Seidlitz, Larry et al. "The Relationship between Income and Subjective Well-Being: Relative or Absolute?" Social Indicators Research 28, (1993): 195-223.

Diener, Marissa and Diener, Carol, "Factors Predicting the Subjective Well-Being of Nations." Journal of Personality and Social Psychology 69, no. 5 (1995): 851-864. and Eunkook, Suh. "Measuring Quality of Life: Economic, Social and Subjective Indicators." Social Indicators Research 40, no. 1-2 (1997): 189-216. and Suh, Eunook Mark, "National Differences in Subjective Well-Being". In WellBeing: The Foundations of Hedonic Psychology, edited by Daniel Kahneman, Ed Diener and Norbert Schwartz, 434-450. New York: Russell Sage Foundation, 1999.

Di Tella, Rafael, MacCulloch, Robert J. and Oswald, Andrew J., "The Macroeconomics of Happiness", LSE Centre for Economic Performance, The Labour Market Consequences of Technical and Structural Change, Discussion Paper no. 19, 1997.

Doyal, Len and Gough, Ian. A Theory of Human Need. Basingstoke: Macmillan Education, 1991.

Drechsler, L. "Problems of Recording Environmental Phenomena in National Accounting Aggregates." The Review of Income and Wealth 22, (1976): 239-252.

Duesenberry, James S. Income, Saving, and the Theory of Consumer Behavior. Cambridge, Mass.: Harvard University Press, 1949.

Easterlin, Richard A. "Does Economic Growth Improve the Human Lot? Some Empirical Evidence." In Nations and Households in Economic Growth: Essays in Honor of Moses Abramowitz, edited by Paul David and Melvin W. Reder. New York:

Academic Press, 1974. . Birth and Fortune. London: Grant McIntyre, 1980.

. "Will Raising the Incomes of All Increase the Happiness of All?" Journal of Economic Behavior and Organization 27, (1995): 35-47.

Easterly, William, "Life During Growth", unpublished paper, World Bank, March 1999.

Eisner, Robert. The Total Incomes System of Accounts. Chicago: University of Chicago Press, 1989.

Elster, Jon. Ulysses and the Sirens: Studies in Rationality and Irrationality. Revised edn. Cambridge: Cambridge University Press, 1984.

Estes, Richard J. Trends in World Social Development: The Social Progress of Nations, 19701987. New York: Praeger, 1988.

Fisher, Irving. The Theory of Interest as Determined by Impatience to Spend Income and the Opportunity to Invest It. New York: Macmillan, 1930

Floud, Roderick, Wachter, Kenneth W. and Gregory, Annabel. Height, Health and History: Nutritional Status in the United Kingdom, 1750-1980. Cambridge: Cambridge University Press, 1990. 
Fogel, Robert W. "Economic Growth, Population Theory, and Physiology: The Bearing of Long-Term Processes on the Making of Economic Policy." American Economic Review 84, no. 3 (1993): 369-395.

Friends of the Earth website, http://www.foe.org.uk/progress/

Galbraith, John Kenneth. The Affluent Society. Boston: Houghton Mifflin, 1958.

Gershuny, Jonathan, Jones, Sally and Baert, Patrick. "The Time Economy or The Economy of Time: An Essay on the Interdependence of Living and Working Conditions." Unpublished typescript, Universities of Oxford and Bath, 1991.

Gershuny, J. and Halpin, B. "Time Use, Quality of Life, and Process Benefits." In In Pursuit of the Quality of Life, edited by A. Offer, 188-210. Oxford: Oxford University Press, 1996.

Great Britain, Department of the Environment. Government Statistical Service. Indicators of Sustainable Development for the United Kingdom. London: HMSO, 1996. . Sustainability Counts: Consultation Paper on a Set of 'Headline' Indicators of Sustainable Development. 1998.

Hagenaars, Aldi, de Vos, Klaas, and Zaidi, Ashgar. "Patterns of Poverty in Europe" In The Distribution of Welfare and Household Production, edited by Stephen P. Jenkins, Arie Kapetyn, and Bernard M.S. van Praag, 25-49. Cambridge: Cambridge University Press, 1998.

Headey, Bruce and Wearing, Alex. Understanding Happiness: A Theory of Subjective WellBeing. Melbourne: Longman Cheshire, 1992.

Hicks, John. Value and Capital. Oxford: Oxford University Press, 1946.

Hirsch, Fred. Social Limits to Growth. London: Routledge \& Kegan Paul, 1977.

Index 99 team with Clive Payne and David Firth, "Final Consultation: Report for Formal Consultation Stage 2: Methodology for an Index of Multiple Deprivation." Unpublished paper, University of Oxford, 1999.

Inglehart, Ronald. Modernization and Postmodernization: Cultural, Economic, and Political Change in 43 Societies. Princeton: Princeton University Press, 1997.

Inglehart, Ronald, Basánez, Miguel and Moreno, Alejandro. Human Values and Beliefs: a Cross-Cultural Sourcebook: Political, Religious, Sexual, and Economic Norms in 43 Societies; Findings from the 1990-1993 World Value Survey. Ann Arbor: University of Michigan Press, 1998.

Jackson, Tim and Marks, Nic. Measuring Sustainable Economic Welfare -- A Pilot Index, 1950-1990. Stockholm: Stockholm Environment Institute, 1994.

Jackson, T., Marks, N., Ralls, J., et al. Sustainable Economic Welfare in the UK, 1950-1996. London: New Economics Foundation, 1997.

Juster, F. Thomas and Stafford, Frank P., eds. Time, Goods and Well-being. Ann Arbor, Michigan: Survey Research Center, Institute for Social Research, University of Michigan, 1985.

Kahneman, Daniel, Diener, Ed and Schwart, Norbert eds. Well-Being: The Foundations of Hedonic Psychology. New York: Russell Sage Foundation, 1999.

Kapp, K. W. The Social Costs of Private Enterprise. Cambridge, Mass: Harvard University Press, 1950.

Kendrick, "Studies in the National Income Accounts." National Bureau of Economic Research, $47^{\text {th }}$ Annual Report, June (1967).

Kneese, A. V., Ayres, R. Y. and d'Arge, R. C. Economics and the Environment: A Material Balances Approach. Washington, D.C.: Resources for the Future, 1970.

Lebergott, Stanley. Pursuing Happiness: American Consumers in the Twentieth Century. Princeton: Princeton University Press, 1993.

Levy, S. and Guttman, L. "On the Multivariate Structure of Well-being." Social Indicators Research 2, (1975): 361-388.

Loewenstein, George and Elster, Jon, eds. Choice over Time. New York: Russell Sage Foundation, 1992. 
Loewenstein, George, "The Fall and Rise of Psychological Explanations in the Economics of Intertemporal Choice." In Choice Over Time, edited by George Loewenstein, and Jon Elster, 3-34. New York: Russell Sage Foundation, 1992.

Lykken, David and Tellegen, Auke. "Happiness is a Stochastic Phenomenon." Psychological Science 7, no. 3 (1996): 186-189.

Marmot, Michael. "Social Differences in Health Within and Between Populations." Daedalus 123, no. 4 (1994).

Meyer, Carrie A. "The Greening of National Accounts: The Role of Ideas in a Theory of Institutional Change." Unpublished paper, George Mason University, 1999.

Miles, Ian. Social Indicators for Human Development. London: Frances Pinter, 1985.

Mishan, E. J. The Costs of Economic Growth. Harmondsworth: Penguin Books, 1967.

Morris, Morris David. Measuring the Condition of the World's Poor: The Physical Quality of Life Index. Oxford: Pergamon, 1979.

. Measuring the Changing Quality of the World's Poor: The Physical Quality of Life Index. Working Paper No. 23/24, Brown University Center for the Comparative Study of Development, Providence, RI, 1996.

Nordhaus, William D. and Tobin, J. Is Growth Obsolete? New York: NBER 50th Anniversary Colloquium, vol. 5, 1972.

Nordhaus, William D. "Reflections on the Concept of Sustainable Economic Growth." In Economic Growth and the Structure of Long-Term Development, edited by Luigi Pasinetti and Robert M. Solow, 309-325. Basingstoke: Macmillan, 1994.

Nordic Council. Level of Living and Inequality in the Nordic Countries: A Comparative Analysis of the Nordic Comprehensive Surveys. Stockholm: Nordic Council and the Nordic Statistical Secretariat, 1984.

Offer, Avner. "The American Automobile Frenzy of the 1950s." In From Family Firms to Corporate Capitalism, edited by K. Bruland, and P.K. O'Brien, 315-353. Oxford: Oxford University Press, 1998.

. "Epidemics of Abundance: Overeating and Slimming in the United States and Britain since the 1950s." Oxford University Discussion Papers in Economic and Social History, no. 25, October 1998.

Olson, Mancur and Landsberg, Hans H., eds. The No-Growth Society. London: Woburn Press, 1975.

Pigou, Arthur Cecil. The Economics of Welfare. London: Macmillan, 1920.

Packard, Vance O. The Waste Makers. London: Longmans, 1960.

Riesman, David. Abundance for What and Other Essays. London: Chatto, 1964.

Rabin, Matthew. "Psychology and Economics". Journal of Economic Literature 36, no. 1, 1998: 11-46.

Robinson, John P. and Godbey, Geoffrey. Time for Life: The Surprising Ways Americans Use their Time. University Park, Pennsylvania: Pennsylvania State University Press, 1997.

Rowntree, B. S.. Poverty: A Study of Town Life. 4th edn. London: Macmillan, 1902.

Sametz, A. W., "The Measurement of Economic Growth". In Indicators of Social Change: Concepts and Measurements, edited by Eleanor B. Sheldon, and Wilbert E. Moore, 77-96. New York: Russell Sage Foundation, 1968.

Schor, Juliet B. The Overworked American: The Unexpected Decline of Leisure. New York: Basic Books, 1991.

Scitovsky, Tibor. The Joyless Economy. New York: Oxford University Press, 1976.

Sen, Amartya. "The Welfare Basis of Real Income Comparisons: A Survey." Journal of Economic Literature 17, no. 1 (1979): 1-45.

."Capability and Well-Being." In The Quality of Life, edited by Martha Nussbaum, and Amartya Sen, 30-53. Oxford: Oxford University Press, 1993.

Slesnick, Daniel T. "Empirical Approaches to the Measurement of Welfare." Journal of Economic Literature 36, (1998): 2108-2165.

Slottje, Daniel, Measuring the Quality of Life Across Countries: A Multidimensional Analysis. Boulder, Col.: Westview, 1991. 
Smith, James P. "Healthy Bodies and Thick Wallets: The Dual Relation between Health and Economic Status." Journal of Economic Perspectives 13, no. 2 (1999): 145-166.

Snooks, Graeme D. Portrait of the Family Within the Total Economy: A Study in Longrun Dynamics, Australia 1788-1990. Cambridge: Cambridge University Press, 1994.

Stigler, George J. and Becker, Gary S., 'De Gustibus None Est Disputandum'. American Economic Review 67, no. 2 (1977): 76-90.

Stones, M. J., Hadjistavropoulos, Thomas, Tuuko, Holly et al. "Happiness has Traitlike and Statelike Properties: A Reply to Veenhoven", Social Indicators Research 36 (1995): 129-144.

Studenski, Paul. The Income of Nations, Theory, Measurement, and Analysis: Past and Present. New York: New York University Press, 1958.

Terleckyj, Nestor E. Improvements in the Quality of Life: Estimates of Possibilities in the United States, 1974-1983. Washington, D.C.: National Planning Association, 1975.

United Nations Social and Economic Council. Working Group on International Statistics and Co-ordination. "Social Statistics: The Follow-up to the World Summit for Social Development." Unpublished paper, 24 January. New York, 1996.

United Nations Development Programme. Human Development Report 1998. New York: Human Development Report Office, United Nations Development Program, 1998.

Van Praag, Bernard M.S. and Fritjers, Paul, "The Measurement of Welfare and Well-Being: The Leyden Approach". In Well-Being: The Foundations of Hedonic Psychology, edited by Daniel Kahneman, Ed Diener and Norbert Schwartz, 413-433. New York: Russell Sage Foundation, 1999.

Veenhoven, Ruut. World Database of Happiness. http://www.eur.nl/fsw/research/happiness/ "Is Happiness Relative?" Social Indicators Research 24, (1991): 1-34. . "Developments in Satisfaction Research." Social Indicators Research 37, (1996): 146.

."The Study of Life Satisfaction". In A Comparative Study of Satisfaction with Life in Europe, edited by Saris, Willem E., Veenhoven, Ruut, Scherpenzeel, Annette C. and Bunting, Brendan, 11-48. Budapest: Eötvös University Press, 1996.

Weitzman, Martin, "On the Welfare Significance of National Product in a Dynamic Economy" Quarterly Journal of Economics 90, 1 (1976): 156-162.

Wilkinson, Richard, "The Epidemiological Transition: From Material Scarcity to Social Disadvantage?" Daedalus 123, 4 (1994):

World Bank, Poverty Reduction and the World Bank. Annual, Washington DC.

Zolotas, Xenophon. Economic Growth and Declining Social Welfare. Athens: Bank of Greece, 1981. 
